\title{
Effect of protein deficiency on absorption, transport and distribution of $\alpha$-tocopherol in the rat
}

\author{
By O. V. RAJARAM, PREMA FATTERPAKER AND A. SREENIVASAN* \\ Biochemistry and Food Technology Division, Bhabha Atomic Research Centre, \\ Trombay, Bombay 400 085, India
}

(Received 25 November I975 - Accepted 6 September 1976)

\begin{abstract}
The absorption, transport and distribution of $\alpha-\left[{ }^{3} \mathrm{H}\right]$ tocopherol were greatly decreased in protein deficiency. This was reflected in the subcellular distribution of $\alpha-\left[{ }^{3} \mathrm{H}\right]$ tocopherol in livers of protein-deficient rats. The ratio, bound : free for $\alpha-\left[{ }^{3} \mathrm{H}\right]$ tocopherol, also decreased in both serum and liver cytosol. After protein refeeding, absorption, transport and distribution patterns of $\alpha-\left[{ }^{3} \mathrm{H}\right]$ tocopherol for the protein-deficient rats were restored to patterns similar to those of control animals.
\end{abstract}

The importance of protein nutrition in vitamin $\mathrm{E}$ metabolism is not yet clearly understood although there are a few reports indirectly emphasizing their interdependence. It has been reported that in human subjects having a wide variety of clinical symptoms of vitamin $\mathrm{E}$ deficiency, the concentration of low-density lipoproteins influences the concentration of $\alpha$-tocopherol in the serum (Davies, Kelleher $\&$ Losowsky, 1969). This relationship is also exemplified by the work of Muller \& Harries (1969) who have assessed the vitamin E status of children suffering from various malabsorptive states and reported that deficiency of the vitamin is greatest in children suffering from $\alpha$ - $\beta$-lipoproteinaemia, a condition in which the main carrierprotein is absent in the serum. Recent findings from this laboratory have suggested the existence of specific $\alpha$-tocopherol-binding, very-low-density lipoproteins (VLDL) in intestinal mucosa, serum and liver cytosol of the rats and their involvement in absorption, transport and distribution of the vitamin (Rajaram, Fatterpaker \& Sreenivasan, 1973, 1974). The results of these studies have indicated that the concentration of serum VLDL, which is related to the protein status of the animal is an important factor in determining the availability of $\alpha$-tocopherol to various tissues. However, a direct relationship between the level of proteins in the diet and the extent of $\alpha$-tocopherol retention in the body remains to be determined. The present paper is concerned with a study of the effect of protein deficiency, and the refeeding of normal amounts of protein, on the absorption, transport and distribution of $\alpha$-tocopherol in the rat.

\section{EXPERIMENTAL \\ Animals and diets}

Weanling male albino rats of the Wistar strain, weighing between 35 and $40 \mathrm{~g}$, were maintained on a laboratory diet (control diet) which contained $(\mathrm{g} / \mathrm{kg})$ : vitamin-free casein 200, maize starch 66o, cellulose 50 , groundnut oil $5^{\circ}$, salt mixture (US Pharmacopæia, XIV, 1950) 40. The following vitamins were added to this diet

\footnotetext{
* Present address: 72 Pali Hill, Bombay 400 050, India.
} 
$(\mathrm{mg} / \mathrm{kg})$ : thiamin hydrochloride 2, riboflavin 4, pyridoxine 4, choline I000, myoinositol 1000, $p$-aminobenzoic acid 300 , nicotinamide 100 , pteroylmonoglutamic acid 2.5, cyanocobalamin 0.05 , biotin 0.1 , ergocalciferol 0.042 , menaphthone 10 , DL- $\alpha$ tocopherol 50 , retinyl palmitate $I^{\cdot} \cdot{ }^{2}$, calcium pantothenate 10 . After an adjustment period of $\mathrm{I}$ week on this regimen, the animals $(65-70 \mathrm{~g}$ body-weight) were divided into three groups of twenty rats each. Animals in the first group ( $a d$ lib.-fed control) were fed the same diet $a d l i b$., and those in the second group (protein-deficient) received ad lib. the control diet with the protein content reduced to $50 \mathrm{~g} / \mathrm{kg}$ and the starch content increased to $8 \mathrm{rog} / \mathrm{kg}$. Animals in the protein-deficient group were fed ad lib. while those in the third group (pair-fed control) were pair-fed with the control diet. At the end of the $4^{\text {th }}$ week, the protein-deficient animals showed stunted growth and weighed between 85 and $9 \circ \mathrm{g}$. The pair-fed and $a d$ lib.-fed controls weighed about $\mathrm{I} 35$ and $180 \mathrm{~g}$ respectively. The animals were killed for analysis at this period.

For protein refeeding experiments weanling rats in three groups of twenty each, which were maintained as described previously on the control diet, protein-deficient diet and pair-fed control diet respectively for a period of 4 weeks, were then maintained for a further 2 week period with protein refeeding of the protein-deficient group. Refeeding of the diet containing $200 \mathrm{~g}$ casein $/ \mathrm{kg}$ (control diet) to the protein-deficient group was ad lib. Animals from all the groups were then killed for analysis.

\section{Oral administration of $\alpha-\left[{ }^{3} \mathrm{H}\right]$ tocopherol}

DL- $\alpha-\left[5^{-}-\mathrm{CH}_{3}{ }^{-}{ }^{3} \mathrm{H}\right]$ tocopherol ( $\mathrm{mCi}$; Radiochemical Centre, Amersham, Bucks.) was mixed with $12 \mathrm{mg}$ unlabelled $\mathrm{DL}-\alpha$-tocopherol in aqueous ethanol $(95: 5, \mathrm{v} / \mathrm{v})$. The mixture, after evaporation of the solvent, was dissolved in $5 \mathrm{ml}$ olive oil (Campbell Manufacturing Industries, Bombay, India). Appropriate amounts ( $500 \mu \mathrm{Ci} / \mathrm{kg}$ body-weight) of this mixture were administered by stomach tube under light diethyl ether anaesthesia to rats that had been starved overnight. Animals were killed at specified time intervals.

\section{Isolation of liver subcellular fractions}

Rats under diethyl ether anaesthesia had their livers perfused through the hepatic portal vein with ice-cold saline solution $(9 \mathrm{~g} \mathrm{NaCl} / 1)$. After perfusion, which took about $5 \mathrm{~min}$, the liver was quickly excised, weighed and placed in ice-cold $0.25 \mathrm{M}$-sucrose containing $10 \mathrm{mM}$-Tris- $\mathrm{HCl}, \mathrm{pH} 7 \cdot 4$, and $\mathrm{I}$ mM-sodium EDTA. A liver homogenate $(500 \mathrm{~g} / \mathrm{l})$ was prepared in the same medium using a Potter-Elvehjem-type glass homogenizer with a Teflon pestle, giving two strokes at low speed (1000-2000 rev./ $\mathrm{min})$. A portion of this was centrifuged at $105000 \mathrm{~g}$ for $60 \mathrm{~min}$ using an ultracentrifuge (Model L2 65B; Beckman Instruments Inc., Fullerton, California, USA) to give a clear cytosol which was withdrawn with a syringe, without disturbing the upper fatty layer. The remaining portion of the ' $500 \mathrm{~g} / \mathrm{l}$ ' homogenate was diluted to $100 \mathrm{~g} / \mathrm{l}$ with the homogenizing medium. The isolation of the various subcellular fractions was carried out as described by Schneider (1948) with some modifications. The nuclei were sedimented by centrifuging the ' $100 \mathrm{~g} / \mathbf{l}$ ' homogenate at $65^{\circ} \mathrm{g}$ for ro min (Sorvall superspeed RC 2-B centrifuge; Ivan Sorvall Inc., Norwalk, Connecticut, USA). The nuclei-free supernatant was centrifuged at $10000 \mathrm{~g}$ for 
Io min to obtain mitochondria and the mitochondria-free supernatant at $105000 \mathrm{~g}$ for 60 min (Model L2 65 $\mathrm{B}$ ultracentrifuge; Beckman Instruments Inc.) to obtain microsomes. All fractions were washed once by suspending in the 'isolation' medium and sedimenting at appropriate speeds. Care was taken not to lose any fraction during separation or washing. All procedures were carried out at $0-4^{\circ}$.

The mitochondrial contamination of nuclei and microsomes was determined by calculating the specific activity of succinate dehydrogenase ( $E C$ r.3.99.I) in these fractions and expressing it as a percentage of the specific activity recovered in mitochondria. The microsomal contamination of mitochondria was similarly calculated by monitoring the activity of the marker enzyme glucose-6-phosphatase (EC 3.1.3.9) in mitochondria and microsomes.

\section{Isolation of $\alpha$-tocopherol-binding VLDL fractions}

A column ( $18 \mathrm{~mm} \times 500 \mathrm{~mm}$ ), uniformly packed with Sephadex G-200 gel (Pharmacia Ltd, Uppsala, Sweden) and equilibrated with $0.05 \mathrm{M}$-sodium phosphate buffer ( $\mathrm{pH} 7 \cdot 4$ ), was used for the isolation of $\alpha$-tocopherol-binding VLDL of serum and liver cytosol (Rajaram et al. 1974). A sample of serum or liver cytosol containing about $100 \mathrm{mg}$ protein was loaded onto the gel and elution was carried out at $4^{\circ}$ at a flow-rate of $20 \mathrm{ml} / \mathrm{h}$ with sodium phosphate buffer and fractions $(2.5 \mathrm{ml})$ were collected. The extinctions at $280 \mathrm{~nm}$ of the various fractions were measured using a spectrophotometer (Model $\mathrm{QV}_{50}$, Shimadzu Seisakusho Ltd, Kyoto, Japan) with a Io mm light-path cell. The VLDL fraction which carried the $\alpha-\left[{ }^{3} \mathrm{H}\right]$ tocopherol was collected and the radioactivity measured in a liquid-scintillation spectrometer (Model LS-I00; Beckman Instruments Inc.) as described previously (Rajaram et al. 1974).

\section{Determination of bound and free $\alpha$-tocopherol}

To $1 \mathrm{ml}$ serum or liver cytosol was added $0.5 \mathrm{ml}$ trichloroacetic acid (TCA) solution $(100 \mathrm{~g} / \mathrm{l})$ and the precipitated proteins, after centrifugation, were washed once with I $\mathrm{ml} \mathrm{TCA}$ solution. The pellet was dissolved in I $\mathrm{ml}$ formic acid. Portions of the pellet and supernatant fraction samples were applied to strips of Whatman 3 MM filter-paper and radioactivity was measured in a liquid-scintillation spectrometer as described previously (Rajaram et al. 1974).

\section{Other estimations}

Glucose-6-phosphatase was assayed according to Recknagel \& Lombardi (I96I). Succinate dehydrogenase was assayed by the spectrophotometric method of Caplan \& Greenwalt (1968).

Protein determinations were carried out by the method of Lowry, Rosebrough, Farr \& Randall (195I). 


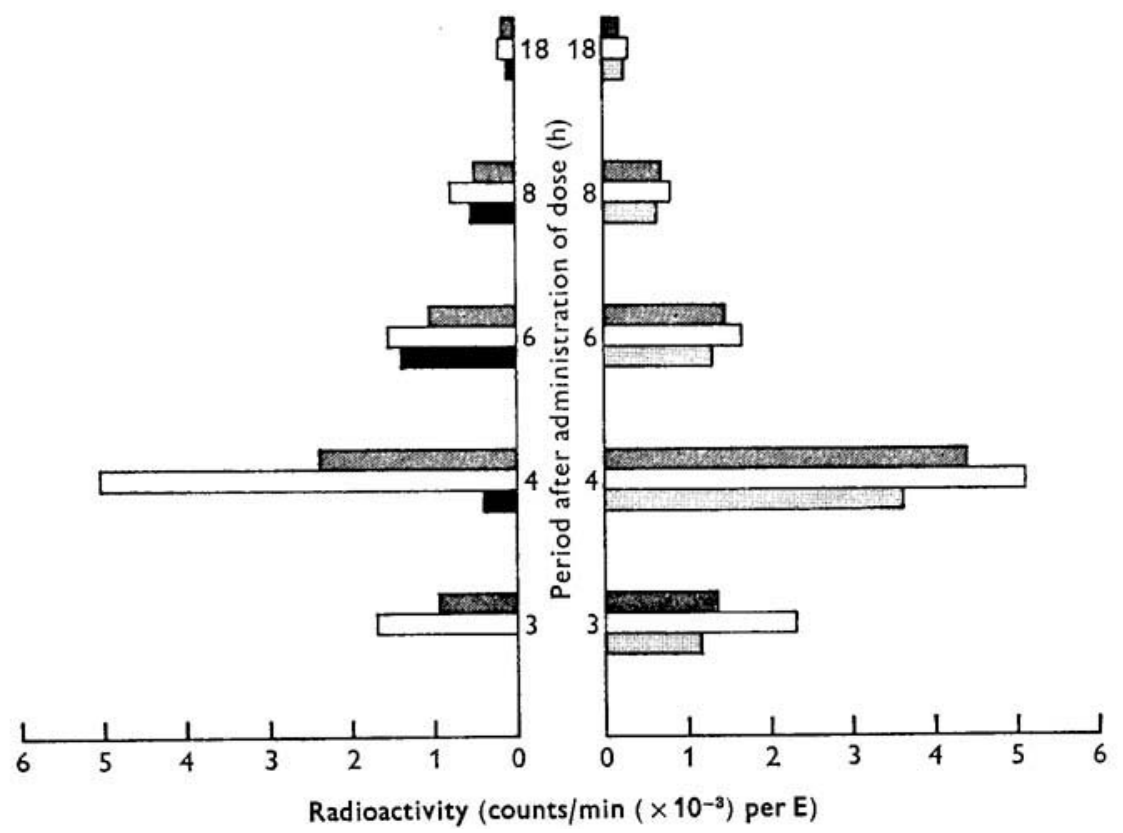

Fig. I. Effect of protein deficiency on the association between $\alpha-\left[{ }^{3} \mathrm{H}\right]$ tocopherol and the verylow-density lipoprotein (VLDL) fraction of serum at various intervals after oral administration of $\alpha_{-}\left[{ }^{3} \mathrm{H}\right]$ tocopherol to rats. The VLDL fraction carrying the $\alpha-\left[{ }^{3} \mathrm{H}\right]$ tocopherol was isolated by Sephadex G-200 chromatography; for details, see p I59. Results are expressed as counts/ $\min \left(\times 10^{3}\right)$ per $E$, i.e. no. of min in a portion of protein solution that gives $E_{280}=I$ in a $10 \mathrm{~mm}$ light-path cell, where $E$ is the extinction at $280 \mathrm{~nm}(\boldsymbol{D})$. Protein-deficient group; (间), protein re-fed, ad lib.-fed group; $(\mathbb{Z})$, protein re-fed, pair-fed control group; ( $\square$ ), ad lib.-fed control group. For details of treatments, see p. 158 .

\section{RESULTS}

Effect of dietary protein status on intestinal absorption of $\alpha$-tocopherol and its transport through serum and liver cytosol

Initially the relative rates of absorption of orally-administered $\alpha-\left[{ }^{3} \mathrm{H}\right]$ tocopherol, as measured in terms of its association with serum and liver cytosol VLDL, were studied. Fig. I shows the effect of protein deficiency and protein refeeding on the association between $\alpha$-tocopherol and the VLDL fraction of serum at various intervals after oral administration of $\alpha$ - $\left[{ }^{3} \mathrm{H}\right]$ tocopherol. The $\alpha$-tocopherol appeared in the serum VLDL fraction of protein-deficient rats at $4 \mathrm{~h}$ after administration. At $6 \mathrm{~h}$ the association between $\alpha$-tocopherol and VLDL fraction reached a maximum and decreased afterwards. In the pair-fed control and ad lib.-fed control animals, however, the radioactivity appeared in the serum as early as $3 \mathrm{~h}$ after administration and reached a maximum at $4 \mathrm{~h}$, decreasing thereafter. The maximum amount of radioactivity in the serum VLDL fraction was considerably reduced in protein deficiency; the reduction in the protein-deficient group was $45 \%$ compared to the pair-fed control and $70 \%$ compared to the ad lib.-fed control. The results shown in Fig. I also indicate that the adverse effects of protein deficiency are reversed on protein refeeding. After 2 weeks of feeding the control diet to protein-deficient rats, the absorption 


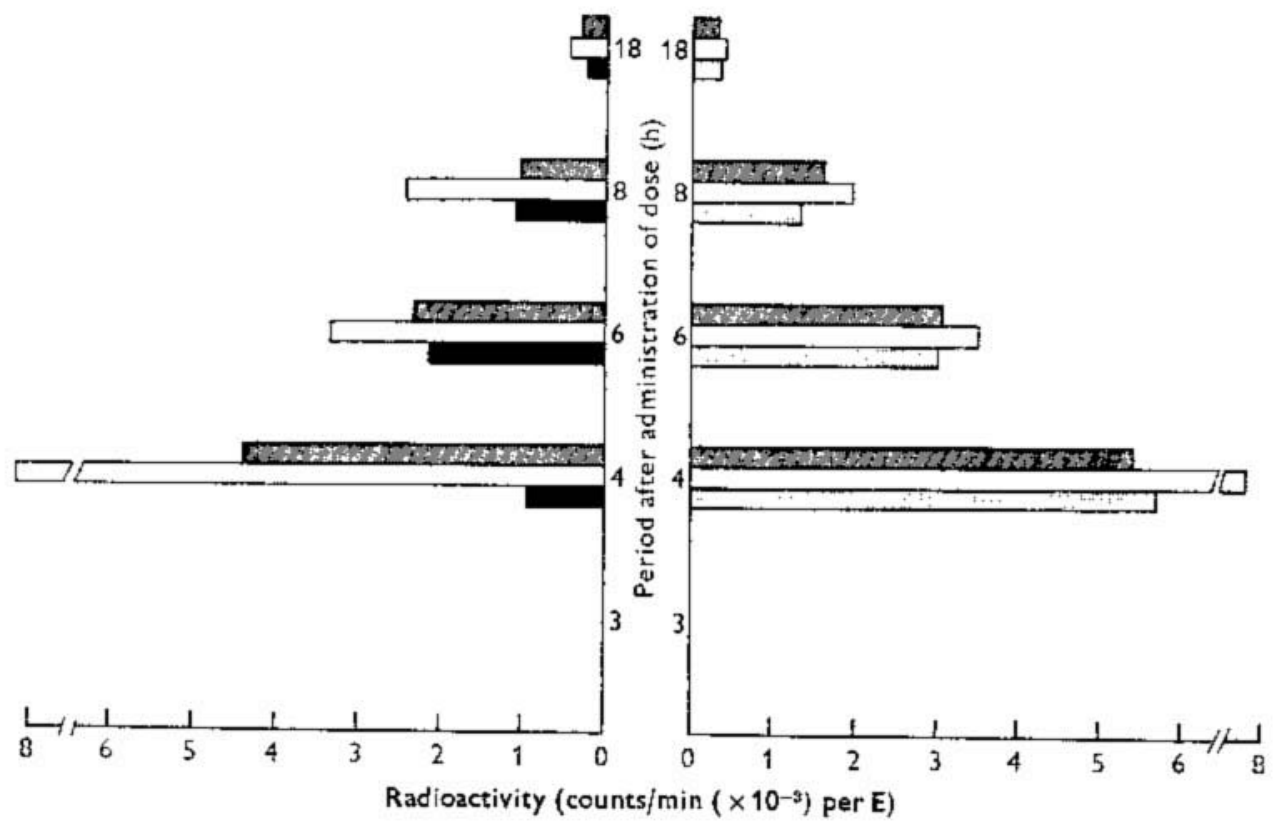

Fig. 2. Effect of protein deficiency on the association between $\alpha-\left[{ }^{3} \mathrm{H}\right]$ tocopherol and the verylow-density lipoprotein (VLDL) fraction of liver cytosol at various intervals after oral administration of $\alpha-\left[{ }^{3} \mathrm{H}\right]$ tocopherol to rats. The VLDL fraction was isolated by Sephadex $\mathrm{G}-200$ chromatography; for details, see p. 159. Results are expressed as counts $/ \mathrm{min}\left(\times 10^{3}\right)$ per E, i.e. no. of counts/min in a portion of protein solution that gives $E_{\mathbf{2 8 0}}=I$ in a $10 \mathrm{~mm}$ pathlength cell, where $E_{280}$ is the extinction at $280 \mathrm{~nm}$. ( $\square$ ), Protein-deficient group; (圈), protein-re-fed ad lib.-fed group; ( $\square$ ) protein-re-fed, pair-fed control group; ( $\square$ ), ad lib.-fed control group. For details of treatments see p. 158 .

pattern of orally-administered $\alpha-\left[{ }^{3} \mathrm{H}\right]$ tocopherol was similar to that of pair-fed control rats. The amount of radioactivity in the VLDL fraction increased and reached levels similar to that of the pair-fed control animals.

The rate of association of $\alpha-\left[{ }^{3} \mathrm{H}\right]$ tocopherol with liver cytosol VLDL fraction of pair-fed and $a d$ lib.-fed control, protein-deficient and protein-refed rats is shown in Fig. 2. Here, again, the amount of radioactivity of the VLDL fraction of proteindeficient rats was decreased by 40 and $70 \%$ compared to pair-fed control and ad lib.-fed control animals, respectively. Maximum association of $\alpha$-tocopherol with this fraction occurred at $6 \mathrm{~h}$ compared with $4 \mathrm{~h}$ for the controls. The absorption pattern as well as the amount of radioactivity of the VLDL fraction was restored to pair-fed control values in protein-refed rats. The results thus indicate that in protein deficiency the absorption of the orally-administered $\alpha$-tocopherol was decreased and delayed.

\section{Dietary protein status and intracellular distribution of $\alpha$-tocopherol in rat liver}

In view of our findings on the impairment of absorption of orally-administered $\alpha-\left[{ }^{3} \mathrm{H}\right]$ tocopherol in protein deficiency, it was of interest to determine whether the subcellular distribution of $\alpha-\left[{ }^{3} \mathrm{H}\right]$ tocopherol was altered in protein deficiency. 


\section{Table 1 . Effect of protein deficiency on the subcellular distribution of $\alpha-\left[{ }^{3} H\right]$ tocopherol in rat liver $\dagger$}

\begin{tabular}{|c|c|c|c|c|c|c|c|c|c|}
\hline \multirow[b]{3}{*}{ Dietary treatment $f$} & \multirow{3}{*}{$\begin{array}{l}\text { Period } \\
\text { after } \\
\text { admin- } \\
\text { istration } \\
\text { of dose } \\
\text { (h) }\end{array}$} & \multicolumn{8}{|c|}{ Radioactivity (counts/min per mg protein) } \\
\hline & & \multicolumn{2}{|c|}{ Nuclei } & \multicolumn{2}{|c|}{ Mitochondria } & \multicolumn{2}{|c|}{ Microsomes } & \multicolumn{2}{|c|}{ Cytosol } \\
\hline & & Mean & $\mathrm{SE}$ & Mean & $\mathrm{SE}$ & Mean & $\mathrm{SE}$ & Mean & SE \\
\hline $\begin{array}{l}\text { Control } \\
\text { Fed ad lib. }\end{array}$ & $\begin{array}{r}4 \\
6 \\
18\end{array}$ & $\begin{array}{r}\text { I } 30 \\
94 \\
28\end{array}$ & $\begin{array}{r}\text { I I.0 } \\
5.8 \\
2.0\end{array}$ & $\begin{array}{r}2182 \\
168 I \\
325\end{array}$ & $\begin{array}{r}182.0 \\
72.0 \\
20.0\end{array}$ & $\begin{array}{r}1610 \\
1095 \\
254\end{array}$ & $\begin{array}{r}121 \cdot 0 \\
72 \cdot 0 \\
20 \cdot 0\end{array}$ & $\begin{array}{r}308 \\
225 \\
34\end{array}$ & $\begin{array}{r}26.0 \\
19.0 \\
3.0\end{array}$ \\
\hline $\begin{array}{l}\text { Pair-fed to protein-deficient } \\
\text { group }\end{array}$ & $\begin{array}{r}4 \\
6 \\
18\end{array}$ & $\begin{array}{l}79 \\
55 \\
21\end{array}$ & $\begin{array}{l}5 \cdot 5 \\
4 \cdot 2 \\
3 \cdot 2\end{array}$ & $\begin{array}{r}\text { I I I } 7 \\
849 \\
223\end{array}$ & $\begin{array}{l}4 I \cdot 2 \\
38 \cdot 0 \\
20 \cdot 3\end{array}$ & $\begin{array}{l}808 \\
547 \\
106\end{array}$ & $\begin{array}{l}35.0 \\
23.2 \\
17.5\end{array}$ & $\begin{array}{r}165 \\
\text { I } 19 \\
22\end{array}$ & $\begin{array}{l}6 \cdot 3 \\
5 \cdot 7 \\
4 \cdot 5\end{array}$ \\
\hline Protein-deficient & $\begin{array}{r}4 \\
6 \\
18\end{array}$ & $\begin{array}{l}x 8 \\
50^{*} \\
22\end{array}$ & $\begin{array}{l}2 \cdot 0 \\
3 \cdot 9 \\
2 \cdot 1\end{array}$ & $\begin{array}{l}225 \\
693^{*} \\
204\end{array}$ & $\begin{array}{l}19.0 \\
42.0 \\
18.0\end{array}$ & $\begin{array}{c}159 \\
485 \\
70\end{array}$ & $\begin{array}{r}13.0 \\
30.0 \\
4.5\end{array}$ & $\begin{array}{c}41 \\
102 * \\
10\end{array}$ & $\begin{array}{r}2.8 \\
11.0 \\
1.0\end{array}$ \\
\hline
\end{tabular}

* Significantly lower than value for pair-fed control group at $4 \mathrm{~h}: P<0.005$.

$\dagger$ For details of experimental procedures, see p. 158 .

$\ddagger$ For details, see p. 158 .

$\alpha-\left[{ }^{3} \mathrm{H}\right]$ tocopherol was administered orally to the rats of different dietary-treatment groups and the distribution of the radioactive $\alpha$-tocopherol among the subcellular fractions of the liver was studied at various time intervals (Table I). It was found that in pair-fed control rats and those given food ad lib. the highest concentration of $\alpha-\left[{ }^{3} \mathrm{H}\right]$ tocopherol, expressed as counts/min per $\mathrm{mg}$ protein, were found in mitochondria. Microsomes, cytosol and nuclei had $\alpha-\left[{ }^{3} \mathrm{H}\right]$ tocopherol concentrations of decreasing order. The values reported here were corrected for contamination of mitochondria by microsomes and vice versa and also for mitochondrial contamination of nuclei. The microsomal contamination of mitochondria was I I \%. Mitochondrial contamination of nuclei and microsomes was 15 and $12 \%$ respectively. It is interesting to note here that, in protein-deficient rats, there was $36-40 \%$ decrease in the amount of radioactivity in the subcellular fractions at $6 \mathrm{~h}$ as compared to pair-fed control at $4 \mathrm{~h}$. The distribution pattern of the $\alpha-\left[{ }^{3} \mathrm{H}\right]$ tocopherol was, however, the same as that of controls. When compared to the control animals fed ad lib., the decrease was $60-70 \%$. The distribution of $\alpha-\left[{ }^{3} \mathrm{H}\right]$ tocopherol and the specific radioactivity of the label in the various subcellular fractions reached pair-fed control values in proteinre-fed rats (Table 2 ).

\section{Effect of protein deficiency on the binding of $\alpha$-tocopherol to proteins}

Previous findings had indicated the significance of binding proteins in the availability of $\alpha$-tocopherol. Since the serum and tissue protein levels are considerably reduced in protein deficiency, it was necessary to determine whether the changes in the absorption and distribution of $\alpha-\left[{ }^{3} \mathrm{H}\right]$ tocopherol could be limited by the binding of the 


\section{Table 2. Effect of protein-refeeding on the sub-cellular distribution of $\alpha-\left[{ }^{3} H\right]$ tocopherol in rat liver}

\begin{tabular}{|c|c|c|c|c|c|c|c|c|c|}
\hline \multirow[b]{3}{*}{ Dietary treatment $\ddagger$} & \multirow{3}{*}{$\begin{array}{l}\text { Period } \\
\text { after } \\
\text { admin- } \\
\text { istration } \\
\text { of dose } \\
\text { (h) }\end{array}$} & \multicolumn{8}{|c|}{ Radioactivity (counts/min per mg protein) } \\
\hline & & \multicolumn{2}{|c|}{ Nuclei } & \multicolumn{2}{|c|}{ Mitochondria } & \multicolumn{2}{|c|}{ Microsomes } & \multicolumn{2}{|c|}{ Cytosol } \\
\hline & & Mean & SE & Mean & SE & Mean & $\mathbf{S E}$ & Mean & $\mathbf{S E}$ \\
\hline $\begin{array}{l}\text { Control } \\
\quad \text { Fed ad lib. }\end{array}$ & $\begin{array}{r}4 \\
6 \\
18\end{array}$ & $\begin{array}{r}154 \\
98 \\
35\end{array}$ & $\begin{array}{l}9 \cdot 0 \\
6.5 \\
2 \cdot 8\end{array}$ & $\begin{array}{r}2300 \\
1714 \\
375\end{array}$ & $\begin{array}{r}165 \\
\text { IOI } \\
24\end{array}$ & $\begin{array}{r}1620 \\
1020 \\
220\end{array}$ & $\begin{array}{r}130 \\
78 \\
19\end{array}$ & $\begin{array}{r}320 \\
210 \\
32\end{array}$ & $\begin{array}{r}22 \cdot 0 \\
16 \cdot 5 \\
5 \cdot 8\end{array}$ \\
\hline $\begin{array}{l}\text { Pair-fed to protein-re-fed } \\
\text { group }\end{array}$ & $\begin{array}{r}4 \\
6 \\
18\end{array}$ & $\begin{array}{r}112 \\
78 \\
24\end{array}$ & $\begin{array}{l}7.0 \\
6.2 \\
3.0\end{array}$ & $\begin{array}{r}1895 \\
1470 \\
295\end{array}$ & $\begin{array}{r}132 \\
\text { I } 19 \\
23\end{array}$ & $\begin{array}{r}1210 \\
915 \\
190\end{array}$ & $\begin{array}{r}52 \\
\text { IIO } \\
21\end{array}$ & $\begin{array}{r}270 \\
189 \\
23\end{array}$ & $\begin{array}{r}9.0 \\
\text { I1.0 } \\
5.0\end{array}$ \\
\hline Protein-re-fed & $\begin{array}{r}4 \\
6 \\
18\end{array}$ & $\begin{array}{l}98 * \\
65 \\
20\end{array}$ & $\begin{array}{l}8 \cdot 4 \\
9 \cdot 0 \\
2 \cdot 3\end{array}$ & $\begin{array}{l}1672^{*} \\
1280 \\
260\end{array}$ & $\begin{array}{r}112 \\
95 \\
19\end{array}$ & $\begin{array}{c}1007^{*} \\
690 \\
140\end{array}$ & $\begin{array}{l}80 \\
66 \\
16\end{array}$ & $\begin{array}{l}280^{*} \\
172 \\
30\end{array}$ & $\begin{array}{r}12 \cdot 0 \\
8 \cdot 0 \\
2 \cdot 8\end{array}$ \\
\hline
\end{tabular}

* Not significantly different from the pair-fed control group at $4 \mathrm{~h}: P>0.25$.

$\dagger$ For details of experimental procedure, see p. 158 .

$\ddagger$ For details, see p. ${ }_{5} 8$.

vitamin to the apoprotein. $\alpha-\left[5-\mathrm{CH}_{3}{ }^{3} \mathrm{H}\right]$ tocopherol was administered orally to rats and the amounts of total, protein-bound and free radioactivity in serum and liver cytosol were determined. It is apparent from Table 3 that in protein deficiency the protein-bound and free $\alpha-\left[{ }^{3} \mathrm{H}\right]$ tocopherol content of both serum and liver cytosol of protein-deficient rats were reduced considerably. The protein-bound radioactivity was decreased by $42 \%$ in serum and liver cytosol compared with pair-fed control rats. However, the amount of free radioactivity, although decreased, was not affected to the same extent in serum and liver cytosol of these rats. This resulted in an altered ratio, bound:free, which decreased by $17 \%$ for serum and $7 \%$ for liver cytosol. On protein refeeding the protein-bound and free $\alpha-\left[{ }^{3} \mathrm{H}\right]$ tocopherol concentration reached those of the pair-fed control (Table 4).

\section{DISCUSSION}

The present studies clearly indicated that the protein status of the rat greatly influences the absorption and subcellular distribution of $\alpha-\left[{ }^{3} \mathrm{H}\right]$ tocopherol. Since we have previously observed that the concentration of serum VLDL is important for the optimal transfer of the vitamin across the intestine (Rajaram et al. 1974), it can be concluded that a reduced serum protein concentration has caused the impairment of absorption of $\alpha-\left[{ }^{3} \mathrm{H}\right]$ tocopherol that is found in protein-deficient rats. The decreased and delayed absorption of orally-administered $\alpha-\left[{ }^{3} \mathrm{H}\right]$ tocopherol, in protein deficiency, was also reflected in the $\alpha-\left[{ }^{3} \mathrm{H}\right]$ tocopherol level in subcellular fractions of liver. These results are similar to those reported by Adhikari, Vakil \& Sreenivasan (I968), who found that the mobilization and liver storage of vitamin A are considerably affected in protein-deficient rats. In both serum and liver cytosol, the level of protein-bound 


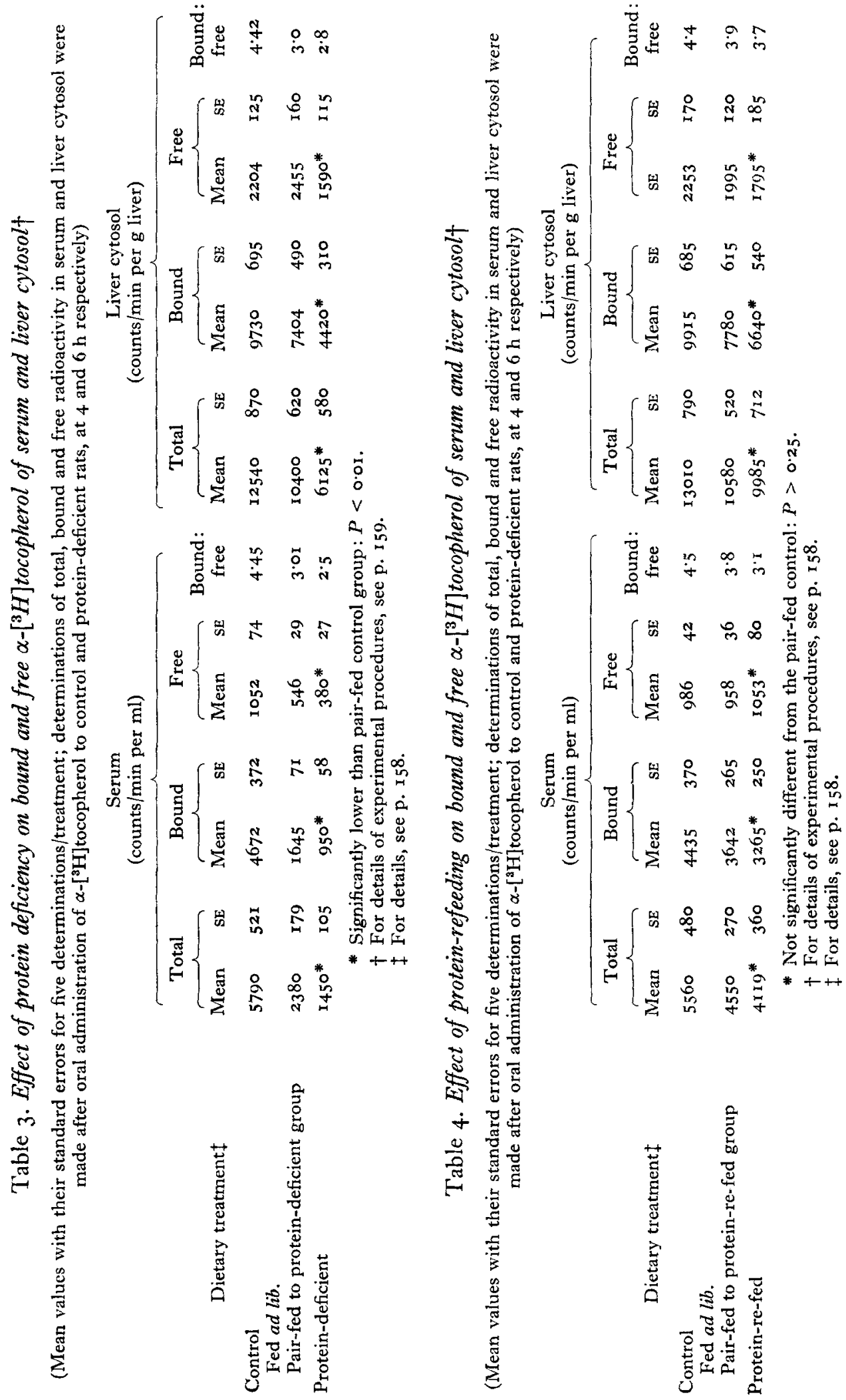


$\alpha-\left[{ }^{3} \mathrm{H}\right]$ tocopherol was decreased. However, the free $\alpha-\left[{ }^{3} \mathrm{H}\right]$ tocopherol content, though decreased, was not affected to the same extent.

Mention may be made here of the work of Tinberg \& Barber (1970) who have studied the binding of $\alpha$-tocopherol in vitro to the structural protein (SP)-lipid micelle complex from microsomes and related this binding to the antioxidant action of $\alpha$-tocopherol. Their results indicate that the inhibitory effect of $\alpha$-tocopherol on lipid peroxidation of rat liver microsomal membrane is due to its binding to the structural proteins of microsomes. In fact, a close relationship has been found between the extent of inhibition of lipid peroxidation in the SP-lipid micelle complex and the amount of $\alpha$-tocopherol bound. According to Tinberg \& Barber (1970), the interaction of $\alpha$-tocopherol with membrane structural proteins could lead to decreased removal of the vitamin from the cell with a corresponding increase in antioxidant activity. Although the question of whether $\alpha$-tocopherol acts only as an antioxidant in vivo remains open, these studies nevertheless emphasize the importance of binding, perhaps for incorporation of the vitamin in the membrane to perform its metabolic function. In the present study, it was found that the decrease in protein-bound vitamin is a result of a reduction in the apoprotein pool. The significance of the binding of this vitamin to cellular proteins could be better understood if the alterations in bound and free forms of $\alpha$-tocopherol were studied under a variety of conditions affecting the metabolism of this vitamin.

\section{REFERENCES}

Adhikari, H. R., Vakil, U. K. \& Sreenivasan, A. (1968). Indian F. Biochem. Biophys. 5, I32. Caplan, A. T. \& Greenwalt, J. W. (1968). F. Cell Biol. 36, I5.

Davies, T., Kelleher, J. \& Losowsky, M. S. (I969). Clinica chim. Acta 24, 43 I.

Lowry, O. H., Rosebrough, N. J., Farr, A. L. \& Randall, R. J. (1951). F. biol. Chem. 193, 265.

Muller, D. P. R. \& Harries, J. T. (1969). Biochem. F. 112, 28P.

Rajaram, O. V., Fatterpaker, P. \& Sreenivasan, A. (I 973). Biochem. biophys. Res. Commun. 52, 459.

Rajaram, O. V., Fatterpaker, P. \& Sreenivasan, A. (1974). Biochem. F. 140, 509.

Recknagel, R. O. \& Lombardi, B. ( (961). F. biol. Chem. 236, 564.

Schneider, W. C. (1948). Ұ. biol. Chem. 176, 259.

Tinberg, H. H. \& Barber, A. A. (1970). F. Nutr. 100, 413.

US Pharmacopoeia, XIV (I950). p. 789. 